\title{
Global Corporate Governance: Implications For A Functionally Harmonized Legal Infrastructure
}

Mark S. Blodgett, (mblodget@suffolk.edu), Suffolk University Stephen A. Kane, (skane@suffolk.edu), Suffolk University

\begin{abstract}
As developing and centrally planned economies shift toward decentralized market economies, they will revise their corporate governance rules to attract foreign investors and foster economic growth. However, the expansion of firms internationally creates the immediate problem of crossborder bankruptcy and policy makers will eventually have to turn to functional harmonization of national bankruptcy laws as well as other means of corporate governance to maintain fairness and to facilitate a freer flow of cross-border investment. We propose three major changes to global governance: (1) a functionally harmonized system of bankruptcy laws that supersede national bankruptcy laws (2) contractual corporate governance via securities exchange listing and (3) arbitration as a means to enforce global recourse.
\end{abstract}

\subsection{Introduction}

A

s the world economy integrates, economic forces may compel the legal incorporation, bankruptcy and other corporate governance systems to functionally harmonize. Laws provide the necessary infrastructure for business associations (corporations, partnerships, joint ventures, etc.), contracting, and in the event of breach or default, recourse. Without a system of laws delineating investor rights, many investments would not occur. The increased harmonization of national laws will help international business to flourish.

Shareholders require adequate corporate governance to monitor and constrain management. Corporate governance includes accounting disclosures, shareholder voting rights, and insider trading restrictions. Minority shareholders are especially vulnerable. They need protection against blocks of shareholders or managers that might form coalitions and expropriate wealth from them.

Debt holders require legal covenants and recourse. Covenants restrict managers from changing business plans and engaging in riskier activities that benefit managers and shareholders at the expense of debt holders. Recourse helps investors avoid or mitigate losses when there are defaults and generally facilitates assets moving from lower return uses to higher return uses.

As developing and centrally planned economies shift toward decentralized market economies, they will revise their corporate governance rules to attract foreign investors and foster economic growth. However, the expansion of firms internationally creates the immediate problem of cross-border bankruptcy and policy makers will eventually have to turn to functional harmonization of national bankruptcy laws as well as other means of corporate governance to maintain fairness and to facilitate a freer flow of cross-border investment. We propose three major changes to global governance: (1) a functionally harmonized system of bankruptcy laws that supersede national bankruptcy laws (2) contractual corporate governance via securities exchange listing and (3) arbitration as a means to enforce global recourse.

Readers with comments or questions are encouraged to contact the authors via email. 


\subsection{Functional Harmonization}

Functional harmonization does not require corporate governance rules to be identical. Some variation in rules is often desirable as is evident in State exemptions to the Uniform Commercial Code. Functional harmonization only requires that the laws in different countries perform similar functions. Differences in regulation allow for experimentation that may lead to beneficial changes in governance through competition among nations to attract investment (and under our proposal stock exchanges to attract listings). Due to competition for investment, economic theory suggests that corporate governance rules that induce less efficient resource allocations will perish over time. Harmonized systems of laws are not new but neither do they have a long tradition.

The United Nation's Commission on International Trade Law (UNCITRAL) allows for alignment of relief by recognizing foreign proceedings in its Model Law on Cross-Border Insolvency (UNCITRAL (1998)). One advantage of doing this is fraud prevention, a growing concern in the global economy (UNCITRAL (1998)). However, UNCITRAL'S attempt at harmonization does not include national law or proceedings (UNCITRAL (1998)). For cross-border financing, it is still essential to know and to deal with national laws that may not be reached by UNCITRAL and may not adhere to U.S. notions of adequate and efficient recourse. "When deciding how to structure the transaction, the essential question is the extent to which the investors providing the financing will be repaid in the event of the local law equivalent of a bankruptcy case." (Schwarcz (2000), p. 239) Not all legal systems have clear or practical procedures for "perfection" (establishment of creditor rights beyond attachment) and there may not be a filing system for establishing the priority of creditors (Schwarcz (2000)). These are well-defined aspects of U.S. bankruptcy law that help to promote fairness and prevent fraud. This protection of creditors is necessary to ensure a more just and efficient system of recourse. Hence, financing in countries with less developed bankruptcy laws and corporate governance pose interesting challenges. Harmonization of national laws will complete the system of cross-border insolvency laws and encourage cross-border financing because creditors will possess comparable knowledge and reassurance of recourse.

\subsection{Corporate Governance}

Corporate governance is more encompassing than legal infrastructure per se. Investors use accounting disclosures to monitor management and to restrain them from expropriating wealth. More transparent accounting makes cash flows easier to evaluate and these investments more liquid for investors. Like legal infrastructure, accounting rules vary from country to country. All else equal, countries with more transparent disclosure are more attractive places for both equity and debt investment. Shareholder rights vary across countries, as well. In the United States, shareholders may oust bad management and even sue them for neglecting their fiduciary duties to shareholders. Strong rules and rights are important, but to be effective, shareholders need enforcement mechanisms, too (Modigliani and Perotti (1998)). Because investors have a choice in where they choose to invest, it is natural that investors will prefer regions with corporate governance rules that favor investors.

Often there are inferior substitutes, functionally inadequate means, to strong governance to protect investors. For example, France lacks strong legal enforcement of contracts. To fill this gap, France requires firms to pay dividends and maintain capital reserves (La Porta, Lopez-de-Silanes, Schliefer, and Vishny (1998)). Some Republics of the former Soviet Union have weak legal systems and enforcement. To compensate, they import legal services from the United States and entrepreneurs often employ the services of extra-legal Mafia organizations to enforce contracts (Hay, Schliefer, and Vishny (1996)). Most countries have weak accounting standards. This makes it difficult for outside investors to monitor management. Further, except for the U.S. (takeover threat and class action law suits) and the U.K. (takeover threat and judges who have a tradition of being investor friendly), there are a few mechanisms to protect minority shareholders. Consequently, firms located elsewhere tend to be closely held by company insiders (La Porta, Lopez-de-Silanes, Schliefer, and Vishny (1997)).

For many developing countries, the U.S. legal infrastructure for corporate governance may well be one worth adapting. For instance, despite a large trade imbalance between the U.S. and Japan, the dollar did not drop substantially compared to the Yen, as it likely would have if the Japanese had not invested heavily in the U.S. A 
large foreign investment base helps the U.S. enjoy strong economic growth even though U.S. citizens engage in heavy consumption and save little compared to other nations.

The U.S. enjoys the consumption party, but does not have to suffer as harsh a hangover due to foreign investment here that spurs economic growth. The U.S. is an attractive place for foreigners to invest. It is a resource rich country with strong incorporation, accounting and bankruptcy laws. The U.S. governance system lowers the rate of return required by foreign investors, and demonstrates that lawyers by creating an investor favorable legal infrastructure contribute to economic growth. Additionally, the U.S. benefits despite its inadequate investment in education, because talented foreigners chose to immigrate to the U.S., since it is a good place to conduct commerce. It is a premise of this paper that other countries will see the advantages offered by strong governance, and that they will copy it to attract foreign investment. Otherwise, this strong corporate governance can be initiated through contract.

Contracting with U.S. securities exchanges is a way to ensure more effective corporate governance (Coffee (1999)). As a requirement to listing on an U.S. exchange, foreign firms must agree to corporate governance provisions including fair and efficient bankruptcy laws. This is a way to spur harmonization and demonstrate its benefits. Enforcement of these contracts can occur through the arbitral process, a globally recognized method of dispute resolution.

\subsection{Arbitration}

A global system of arbitration is now in place that allows for quick and efficient resolution of disputes without jurisdictional obstacles. Arbitration clauses are common in international contracts today and can be part of the securities exchange listing requirements. Managers might select a corporate governance system and court of arbitration by choosing exchanges where they list their companies.

Exchanges have a strong incentive to foster investor favorable arbitration rulings in order to protect any economic rents they might earn from listing fees and subsequent economies of scope from providing liquidity services. Thus, exchanges might want to control their own court of arbitration. Major arbitral courts such as that of the International Chamber of Commerce (ICC) located in Paris and the London Court of Arbitration serve as potential models for stock exchanges to emulate.

Through more and greater treaty attempts at harmonized legal systems, contractual corporate governance and enforcement by arbitration, functional harmonization of national bankruptcy laws can be accomplished and open a new era in global investment. The following discussion elaborates on the entry and exit costs of functionally harmonized legal infrastructures and effects of allocation efficiency.

\subsection{Policy Overview: Entry \& Exit Costs}

A functionally harmonized legal infrastructure may improve allocation efficiency. Allocation efficiency requires that investment dollars flow into their highest and best uses without regard to national borders. Besides opportunity cost benefits, there are also diversification benefits for investors. If two national economies are not fully integrated, then their economic cycles will not be fully synchronized. Hence, investment opportunities in one country will be less than perfectly positively correlated with investment opportunities in another country. Nevertheless, there are many obstacles that prevent the free flow of investment funds across borders, not withstanding, a lack of a similar legal infrastructure.

Entry and exit costs are barriers to the free flow of investment. Lower entry and exit costs reduce the risk of investments. Entry costs include the cost of incorporation as well as the fixed cost that a business must incur to engage in commerce. For instance, a manufacturer has substantial capital investment in plant and equipment. It also has substantial entry costs in setting up networks of suppliers and retailers. For instance, a foreign automobile manufacturer might elect not to go out of business when the exchange rate is unfavorable and car sales are weak (even unprofitable) because it would incur substantial start up costs when exchange rates changed and selling cars 
was profitable. Instead, it might choose to keep a skeletal retail network in place because the cost of acquiring a network of retail dealers when needed is too expensive.

Many businesses lose economic value when creditors liquidate them, because creditors might only recover the salvage value of assets utilized for production. Liquidation proceedings may forfeit the economic value of the firm associated with it being a going concern. Consequently, courts may grant financially distressed firms protection against their creditors while they attempt to reorganize into viable entities. Such reorganizations may benefit shareholders at the expense of debt holders who are delayed in recovering their collateral. Exit costs (liquidation expenses) are substantial when the assets utilized for production do not have good alternative uses. This lowers the salvage value of assets. For example, with the advent of electronic payment instruments, modern telecommunications, and information gathering and processing capacities, the value of brick and mortar of a bank branch may no longer be high. Banks may desire to close branches and place brick and mortar into higher and better uses. To transition out of physical branches, banks face exit costs. They must find a buyer for the brick and mortar and settle on a price. This price will depend on the alternative uses for the branch. Not withstanding, bank management must reallocate current employees working in the branch while maintaining valuable customer relationships.

\subsection{Path Dependence}

Regulation evolves over time as it adapts to new technology and circumstances. It cannot adapt instantaneously. A financial regulatory system includes existing laws, regulatory enforcement, and institutional stakeholders. Path dependence recognizes that the initial state of a financial system influences the future paths as the system evolves. A major advantage of common law over civil is that it is better suited for change, because it is built up by legal precedence of disputes making it easier to adapt and evolve through time.

Various stakeholders and the present legal system itself constrain change. More efficient resource allocation leads to more economic output overall. Nevertheless, the promise of increased output may not be sufficient by itself to overcome strong short run resistance.

Many entrenched stakeholders benefit from the status quo. Managers may prefer weak accounting disclosure if it helps them earn higher explicit or implicit salaries (through consuming prerequisites such as nice offices and large expense accounts). Similarly, they may prefer weak shareholder rights if it prevents them from being fired for expropriating wealth from shareholders. In less developed countries, wealthy families may earn economic rents from the existing legal infrastructure, because investors may have to incorporate through them. Naturally, self-interested parties will use their political connections to oppose legal infrastructure harmonization actions that will expropriate wealth from them (La Porta, Lopez-de-Silanes, Schliefer, and Vishny (2000)).

Better-developed countries benefit from the status quo, too. Better corporate governance may lower the required anticipated return on investment in developed countries and allow more investment to take place there at the expense of less developed countries. Further many talented immigrants from less developed countries move to more developed countries to study and subsequently establish residence. The developed countries reap the benefit from the investment that less developed countries made in these talented immigrants since they only had to expend resources to educate them at the college level.

The integrity of a regulatory system prevents it from contorting in various ways, too. Loopholes and innovations may be necessary politically to perturb a regulatory regime from its current state to a new and improved state of corporate governance and subsequent higher economic performance.

Interested parties in the regulatory debate cannot foresee all potential loopholes and innovations, because future technological innovation is impossible to perfectly anticipate. Parties that perceive that they would benefit from the reform and subsequent economic output have an incentive to seek out loopholes and innovations. Loopholes may catch many parties by surprise. This might deter them from preventing the reform. Loopholes may also circumvent opposing parties by removing them from the decision process, too. Alternatively, loopholes might 
appease potential opposition by sufficiently protecting their stake in the short run, while still permitting the new activity to take place.

We consider electronic check presentment. Due to technological advances, many banks have switched from using microfilm technology to using electronic imaging technology to archive checks. After switching archiving technology, it was only natural for banks to want to lower their operations cost by exchanging electronic images of checks (photo document files) through an electronic mail system instead of physically exchanging paper checks. Legalizing electronic check presentment might have required the banking industry to change to uniform commercial code in all fifty states or to have Congress pass national legislation that superseding the state uniform commercial codes. Before Congress acted, many large banks formed a small value payments company to facilitate electronic check presentment. Member banks made a multilateral agreement that allow members to electronically present checks from the customer's accounts for payment to each other.

Stock market exchanges have an influence over corporate governance that supersedes many national laws. For instance, a foreign firm may cross-lists on NASDAQ or the NYSE and be subject to Security Exchange Commission regulations in the United States. U.S. Listing bonds firms to American regulation. Managers agree to follow Generally Accepted Accounting Principles. Market participants are subject to insider trading restrictions and other SEC disclosure regulations. U.S. listing grants shareholders voting rights over the members of the boards of trustees. The success of American depository receipts (ADRs) shows that investors prefer a common set of rules when conducting initial public offerings and subsequent investing. ADRs may also be seen as a substitute for common investment rules among countries. Investors use familiar SEC regulation and therefore a legal infrastructure that better bonds managers to shareholders.

\subsection{Enforcement}

We suggest an innovation that might allow American style corporate governance abroad, that is, executive stock option plans to compensate managers and align them with the shareholders and class action litigation to protect minority shareholders from expropriation. Stock exchanges might establish and maintain a binding court of arbitration to settle corporate governance disputes between stakeholders with foreign companies that chose to list with them. Sovereigns could agree to enforce legal judgements of court sponsored by the exchange. In this way, managers by choosing which exchanges that they listed their securities would select a corporate governance infrastructure that might supersede national laws without having to change them. Because stock exchanges would sponsor arbitrage courts, they would have a strong incentive to be investor friendly to attract business, too. Thus, exchange listings could serve as a loophole that would allow different corporate governance structures to compete with each other in the same industries and countries. It might even be possible to develop compelling evidence concerning the debate whether economic growth rate disparities are due to the legal infrastructure or the physical environment.

\subsection{Interstate Bank Branching}

For many years, it was politically impossible to pass legislation that allowed interstate bank branching in the U.S. Edward Kane (1996) argues that too many parties benefited from the status quo. Borrowers and developers benefited from lower interest rates offered in States that had lower interest rates. They did not have to compete with the better investment opportunities offered by other States. Until the advent of mutual funds, interested parties could politic to prevent funds from crossing state borders. Since most households invested in bank time deposits instead of mutual funds, it was feasible to keep deposit within a state. Indeed, politicians were receptive to concerns that their state might experience slower economic growth due to investment outflows.

Because investments tend to increase economic growth, many states have incentives to create an attractive investment environment, just as many states have incentives to create an attractive business environment. For instance, the State of Delaware has created a favorable legal environment to incorporate. Delaware has reaped the 
jobs and tax revenue created by these operations. Similarly, States and foreign countries face similar incentives in attracting outside investment.

Unlike foreign countries, States have more similar bankruptcy and incorporation laws that are favorable to investors. Even so, it was difficult to move funds across state borders. Due to a tremendous outflow of bank deposits into mutual funds, however, things changed. Mutual funds attracted and allocated funds on a national basis. They also decentralized the allocation of credit. Over time, mutual funds and multi-State bank holding companies bid down the large discrepancies in interest rates offered by banks. Only after the U.S. achieved functional interstate bank branching (evidenced by the mitigation of interest rate disparities between states) was it possible to pass interstate bank branching in 1994 (Kane (1996)).

\subsection{Time Frame}

It took thirty-eight years from the advent of multi-state bank holding companies to the enactment of interstate bank branching. Yet, States started out with fairly similar cultures and laws. What will happen internationally with legal function harmonization when there are much more disparities? Will a functionally harmonized legal infrastructure take as long? First, investors may invest globally. Consequently, the decision to allocate capital can be more decentralized. Second, foreign countries have strong incentives to change their legal infrastructure to garner foreign investment. Third, technology is speeding up the process. Telecommunications are making an integrated world economy a reality. It is now possible to communicate in real-time with a business partner halfway around the globe cheaply and effectively. This was less feasible ten or twenty years ago.

Despite high cultural barriers, we argue that the corporate governance systems that perseveres under competition between exchange listing and sovereigns who seek to garner investment might harmonize in function more quickly than attempts to coordinate legal infrastructure internationally.

Listing on an American stock exchange benefits managers by potentially raising stock valuations. This helps managers when they hold a direct equity stake, or if they compensated with stock options. American listings also make it easier for potential merger partners to evaluate them, and this may facilitate stock for stock exchanges in acquisitions. Mergers may benefit managers when they receive handsome deals for acquiescing to a merger, or if they wind up managing larger and more successful enterprises. An exchange that innovates to improve corporate governance may gain an incumbent position. This is generally desirable and especially so in an industry with high fixed costs and low marginal costs, because incumbents may earn large economic rents. We consider the competition for incorporation chartering between states. John Coffee (1999) argues that Delaware has a strong incumbent position. Another state cannot simply copy Delaware's laws and challenge them. Delaware has ambiguous laws that require frequent judicial interpretation. Delaware has a long history of making investor favorable rulings. Since Delaware is a small state that is dependent of the revenue generated from corporation chartering, Delaware may credibly promise to continue to deliver investor favorable rulings. Consequently, another state faces substantial barriers to entry to challenge Delaware. Due to the strong incumbent position, Delaware has been able to de facto harmonize incorporation laws. Similarly, a stock exchange with a strong incumbent position in fostering better corporate governance through contracting and arbitration rulings may be able to de facto harmonize corporate governance systems, too.

\subsection{Multinational Corporations}

Multinational corporations face many advantages. They can produce more and different products that allow them to capture many production economies scope and scale. They diversify many risks, too. For instance, they may sell their products to consumers in many countries. This may allow them to ride out economic downturns in one part of the world where sales are sluggish, since in another part of the world sales may be brisk due to an economic upturn there. Production levels can be steadier, and this allows them to maintain production levels near capacity when it is cheaper to produce. Manufacturers may experience fewer problems with labor strikes and suppliers, since they can use competition from around the world. This competition keeps labor and other supply costs lower. They may select the location of their factors of production to reduce costs. For instance, an airplane 
manufacturer may locate in a region that has relatively cheap hydroelectric power and proximity to the raw materials needed to make aluminum. Further, manufacturers may engage in regulatory arbitrage. For instance, they might elect to manufacture a product in a country where pollution restrictions are less severe. This allows manufacturers to lower their production costs. A multinational corporation faces disadvantages, too. It must comply with different legal systems, regulations and laws including insolvency laws and it must be sensitive to different customs and cultures where it does business.

\subsection{Conclusion}

We see a harmonization trend through corporate governance, ADRs, the multinational corporation, U.S. export of legal services to Eastern Europe, and multilateral agreements. Economics suggests that this trend will continue and strengthen, but it is still in its incipiency. Information processing and telecommunications advances that make global business practical have only happened in the last decade. Legal systems change to accommodate economic forces. Countries with barriers to investment will discourage foreign investment and stifle economic growth. Eventually, participants in the global economy will compel sovereigns to functionally harmonize. Through continued and enhanced treaty development, contractual convergence and arbitration, sovereigns will bow to the boom in global investment and seek substantial functional harmonization.

The Authors would like to thank John Coffee, Mike Eddleston, Lin Guo and the participants of the Academy of Legal Studies of Business Conference 2001.

\section{References}

1. Coffee, J. "The Future is History: The Prospects for Global Convergence in Corporate Governance and Its "Implications," Northwestern University Law Review, spring (1999) 641-707.

2. Hay, J., A. Shleifer, and R. Vishny, "Privatization in transition economies: Towards a theory of Legal reform," European Economic Review, 40 (1996) 559-567.

3. Kane, E. "De Jure Interstate Banking: Why only now?” Journal of Money, Credit and Banking, 28:2 May (1996)141-161.

4. Modigliani, F. and E. Perotti, "Security Markets versus Bank Finance: Enforcement and Investors' Protection," International Review of Finance, 1:2 (2000) 81-96.

5. La Porta, R., F. Lopez-de-Silanes, A. Shleifer, R. Vishny, "Legal Determinants of External Finance," Journal of Finance, 52:3 (1997) 1131-1150.

6. La Porta, R., F. Lopez-de-Silanes, A. Shleifer, R. Vishny, "Law and Finance," Journal of Political Economy, 106:6 (1998) 1113-1155.

7. R. La Porta, F. Lopez-de-Silanes, A. Shleifer, and R. Vishny, "Investor Protection and Corporate Governance," Journal of Financial Economics, 58:1 (2000) 3-27.

8. Schwarcz, S., "The Universal Language of Cross-Border Finance," Duke Journal of Comparative and International Law, 8 (2000) 235-254.

9. "UNCITRAL Model Law on Cross-Border Insolvency: Guide to Enactment of UNCITRAL Model Lawon Cross Border Insolvency," Tulane Journal of International and Comparative Law, 6 spring (1998) 415486. 
Notes 